\title{
Zoonotic and Foodborne Transmission of Hepatitis E Virus
}

\author{
Xiang-Jin Meng, MD, $\mathrm{PhD}^{1}$ \\ ${ }^{1}$ Department of Biomedical Sciences and Pathobiology, College of \\ Veterinary Medicine, Virginia Polytechnic Institute and State \\ University, Blacksburg, Virginia \\ Address for correspondence X. J. Meng, MD, PhD, Department of \\ Biomedical Sciences and Pathobiology, Virginia Tech, CRC-Integrated \\ Life Science Building, 1981 Kraft Drive, Blacksburg, VA 24061-0913 \\ (e-mail: xjmeng@vt.edu).
}

Semin Liver Dis 2013;33:41-49.

\begin{abstract}
Keywords

- hepatitis E virus

- HEV

- zoonosis

- foodborne transmission

- zoonotic transmission

- animal reservoirs

Hepatitis $\mathrm{E}$ is an important disease in many developing countries of Asia and Africa with large explosive outbreaks and is also endemic with sporadic or cluster cases of hepatitis in many industrialized countries. The causative agent, hepatitis E virus (HEV), is currently classified in the family Hepeviridae. Thus far, four putative genera of HEV representing mammalian, avian, and fish species have been identified and characterized worldwide. Within the mammalian HEV that infects humans, genotypes 1 and 2 are associated with epidemics and restricted to humans, whereas genotypes 3 and 4 are zoonotic and associated with sporadic and cluster cases of hepatitis E. As a fecal-orally transmitted disease, waterborne transmission is still an important route of HEV transmission especially for large outbreaks associated with genotypes 1 and 2. However, genetic identification of numerous animal strains of HEV and the demonstrated ability of crossspecies infection by these animal strains have significantly broadened the host range and diversity of HEV and raised public health concerns for zoonosis and food safety associated with genotypes 3 and 4 HEV infection. Pigs and likely other animal species serve as reservoirs for HEV. Direct contact with infected pigs and other animals and consumption of contaminated animal meat and meat products pose risks for HEV infection. In this article, the current understanding of the zoonotic and foodborne transmissions of HEV as well as strategies to prevent zoonosis and ensure food safety is discussed.
\end{abstract}

Hepatitis E, an important human disease, is characterized by explosive outbreaks of acute hepatitis in developing countries, and sporadic and cluster cases of hepatitis $\mathrm{E}$ in industrialized countries. $^{1,2}$ The causative agent, hepatitis E virus (HEV), has been genetically identified from humans and several other animal species including pig, chicken, deer, mongoose, rabbit, rat, ferret, and fish. ${ }^{3-5}$ The host range and diversity of HEV have been significantly expanded in recent years. Hepatitis $\mathrm{E}$ is now a recognized zoonotic disease, and pigs and likely other animal species are reservoirs for HEV (-Fig.1). ${ }^{5}$ Direct contact with infected animals and consumption of contaminated animal meat and meat products have been linked to sporadic and cluster cases of acute hepatitis $\mathrm{E}$, thus raising concerns over zoonosis and food safety. ${ }^{3}$ Recently, genotype $3 \mathrm{HEV}$-associat- ed persistent infection has become a significant clinical problem in immunocompromised individuals, ${ }^{6,7}$ which further underscores the clinical importance of these zoonotic genotypes 3 and $4 \mathrm{HEV}$ strains. Here the natural history and emerging zoonotic risks of HEV are reviewed with emphases on the zoonotic and foodborne transmissions of the virus and potential strategies to prevent zoonosis and ensure food safety.

\section{Hepatitis E Virus Nomenclature}

HEV belongs to the family Hepeviridae, and according to the $9^{\text {th }}$ Report of the International Committee on the Taxonomy of Viruses (ICTV), ${ }^{8}$ currently there is a single genus Hepevirus within the family along with a floating species of avian HEV.
Issue Theme Hepatitis E in 2013: Essential Facts, Emerging Concepts and Challenges; Guest Editor, Kris Krawczynski, MD, PhD
Copyright (c) 2013 by Thieme Medical Publishers, Inc., 333 Seventh Avenue, New York, NY 10001, USA. Tel: +1(212) 584-4662.
DOI http://dx.doi.org/ 10.1055/s-0033-1338113. ISSN 0272-8087. 


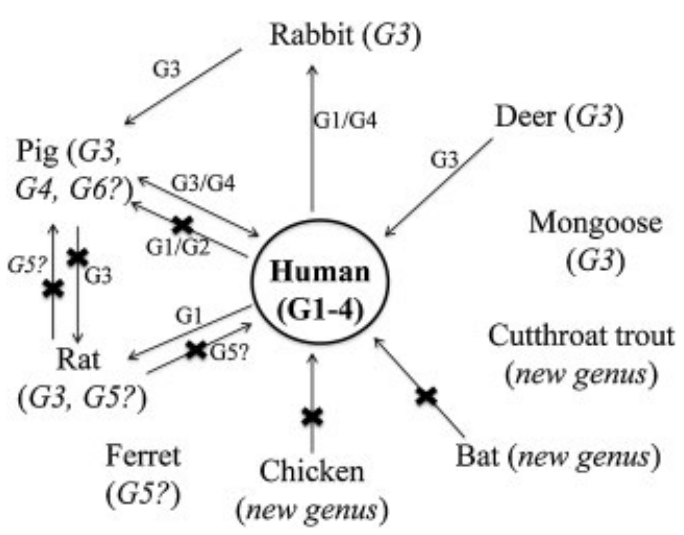

Fig. 1 Animal reservoirs and cross-species infection of hepatitis $E$ virus (HEV). The animal species from which strains of HEV have been genetically identified are indicated. The known (G1-G4) and putative (G5-6?) genotypes as well as the proposed new genus are included in parenthesis of each animal species. The demonstrated ability of cross-species infection by strains of HEV between two animal species is indicated by arrows and the infecting genotypes (next to the arrows). The symbol $X$ on an arrow indicates the inability to infect across species as reported in the literature.

The viruses within the genus Hepevirus all infect mammals and have been genetically identified from humans, pig, mongoose, deer, rat, rabbit, and ferret (-Fig. 1). However, the recent identification of genetically and phylogenetically distinct strains of HEV from several other animal species such as fish and bat ${ }^{9,10}$ warrant reclassification of HEV in the near future.

The genus Hepevirus includes four recognized genotypes and at least two putative new genotypes. ${ }^{8}$ Genotype $1 \mathrm{HEV}$ consists of Asian strains of human HEV that are responsible for large outbreaks in humans. Genotype $2 \mathrm{HEV}$ consists of a single Mexican strain and some African strains of human HEV and is also associated with epidemics in humans. Genotype 3
HEV contains strains from sporadic, cluster, and chronic cases of hepatitis $\mathrm{E}$ in humans and from several animal species including pig, deer, rat, mongoose, and rabbit. Genotype 4 HEV includes strains from sporadic and cluster cases of hepatitis $\mathrm{E}$ in humans and animal HEV strains from pigs and possibly cattle and sheep. ${ }^{3}$ The two putative new genotypes of mammalian hepeviruses include strains of HEV from rat and ferret, ${ }^{11-13}$ and a novel strain of HEV from wild boars in Japan. ${ }^{14,15}$ A tentative genus Orthohepevirus is proposed here to include all these mammalian strains of HEV (-Table 1).

Avian HEV from chicken ${ }^{16}$ is currently classified as a floating species within the family Hepeviridae. ${ }^{8}$ However, avian HEV is genetically and phylogenetically distinct from the mammalian hepeviruses sharing only $\sim 50 \%$ nucleotide sequence identity. ${ }^{17-19}$ Therefore, avian HEV should be classified as a separate genus, ${ }^{4,20}$ and the tentative genus Avihepevirus is proposed here to include all three genotypes of avian HEV worldwide: genotype 1 from chickens in Australia and Korea, genotype 2 from chickens in the United States, and genotype 3 from chickens in Europe and China. ${ }^{19,21,22}$

The novel strain of HEV, cutthroat trout virus $(\mathrm{CTV})^{10}$ isolated from spawning adult trout in the United States, belongs to a new genus as well, and the tentative genus Piscihepevirus is proposed here for CTV. The novel strain of HEV recently identified from bats ${ }^{9}$ is also phylogenetically distinct from the known HEV strains, and thus is proposed to form a tentative genus Chiropteranhepevirus (-Table 1).

\section{The Ever-Expanding Host Range of HEV}

Genetic identification of HEV strains from various animal hosts and the demonstration of cross-species infection by some animal strains of HEV have broadened the host range and genetic diversity of virus ( - Table 1$)^{3,5}$

Table 1 Proposed nomenclature of the hepatitis E virus (HEV)

\begin{tabular}{|l|l|}
\hline Proposed genera & \multicolumn{2}{l|}{ Natural hosts } \\
\hline Orthohepevirus & \multicolumn{1}{l|}{ Man } \\
\hline Genotype 1 & Man \\
\hline Genotype 2 & Man, domestic and wild pig, deer, mongoose, rabbit, rat \\
\hline Genotype 3 & Man, domestic and wild pig, cattle, sheep \\
\hline Genotype 4 & Rat, ferret \\
\hline Putative genotype 5 & Wild pig \\
\hline Putative genotype 6 & \multicolumn{2}{|l}{} \\
\hline Avihepevirus & Chicken (Australia, Korea) \\
\hline Genotype 1 & Chicken (USA, Canada) \\
\hline Genotype 2 & Chicken (Europe, China) \\
\hline Genotype 3 & \multicolumn{2}{|l}{} \\
\hline Piscihepevirus & Brown, Apache, and Gila trouts \\
\hline Cutthroat trout virus & Bat \\
\hline Chiropteranhepevirus & \\
\hline Bat HEV &
\end{tabular}




\section{Domestic Pig}

The first animal strain of HEV, swine hepatitis E virus (swine HEV), was identified and characterized in 1997 from domestic pigs in the United States. ${ }^{23}$ Thus far, two genotypes of HEV, genotypes 3 and 4 , have been identified from pigs worldwide. HEV infection is widespread in swine farms and generally infects pigs of 2 to 4 months of age. The infected pigs are subclinical and generally have a transient viremia lasting for 1 to 2 weeks, and fecal virus shedding lasting for approximately 3 to 7 weeks. Gross pathological lesions were absent in the liver, although microscopic lesions of hepatitis characterized by multifocal lymphoplasmacytic hepatitis and focal hepatocellular necrosis were observed. ${ }^{24}$ The transmission route for $\mathrm{HEV}$ in pigs is fecal-oral and virus-containing feces are the main source of virus for transmission. However, under experimental conditions, infection of pigs with HEV via the oral route of inoculation has been difficult, even though pigs can be readily infected via the intravenous route of inoculation. ${ }^{25,26}$ How HEV maintains in swine herds remains unknown; both genotypes 3 and $4 \mathrm{HEV}$ from pigs are zoonotic and infect humans.

\section{Wild Boar}

Free-living wild boars (Sus scrofa) that are indigenous in many countries are known to harbor HEV. ${ }^{27}$ Human habitation changes from rural to suburban areas, increased agricultural use of lands, deforestation, recreational hunting, and consumption of wild boar meats have increased the chances of contact exposure of wild boars to humans. ${ }^{27}$ The HEV strains identified in wild boars worldwide are mostly genotype 3 , although strains belonging to genotype 4 as well as a putative new genotype have also been detected in wild boars. ${ }^{14,15}$ Like domestic pigs, the genotypes 3 and $4 \mathrm{HEV}$ from wild boars infect humans.

\section{Chicken}

Avian hepatitis E virus (avian HEV) was genetically identified from chickens with hepatitis-splenomegaly syndrome (HSS) in the United States. ${ }^{16}$ Avian HEV shares approximately $80 \%$ nucleotide sequence identity with the big liver and spleen disease virus (BLSV) from chickens in Australia, ${ }^{18,28}$ suggesting that BLS in Australia and HSS in the United States are caused by variant strains of the same virus. Avian HEV shares 50 to $60 \%$ nucleotide sequence identities and common antigenic epitopes in the capsid protein with human HEVs. ${ }^{18}$ At least three genotypes of avian HEV have been identified from chickens worldwide. ${ }^{19,21}$ In the United States, HEV infection in chickens is enzootic, and approximately $71 \%$ of chicken flocks and 30\% of chickens were seropositive for avian HEV antibodies. ${ }^{17,29}$ The morbidity and mortality of HSS or BLS associated with avian HEV infection are low, and avian HEV infection in chickens is mostly subclinical. Gross lesions including subcapsular hemorrhages and enlarged livers were present in some but not all infected chickens, and microscopic hepatitis lesions are characterized by lymphocytic periphlebitis and phlebitis in the livers. ${ }^{30,31}$ Evidence of avian HEV infection in humans is currently lacking. ${ }^{32}$

\section{Rat}

Strains of HEV have now been genetically identified from various species of rats. ${ }^{11,12,33}$ The rat HEV shared only approximately $60 \%$ and $50 \%$ sequence identity with other mammalian HEV and avian HEV, respectively, and thus belongs to a putative new genotype within the proposed Orthohepevirus genus. It remains to be determined if this putative new genotype of rat HEV can infect humans. Most recently, strains of HEV belonging to the genotype 3 have also been identified from rats in the United States, ${ }^{34}$ suggesting that some strains of rat HEV are likely zoonotic and may infect humans.

\section{Rabbit}

A genetically distinct strain of HEV that is related to genotype 3 was identified from rabbits in China, ${ }^{35}$ the United States, ${ }^{36}$ and France. ${ }^{37}$ The rabbit HEV shares approximately 74\%, 73\%, 78 to $79 \%, 74$ to $75 \%$, and 46 to $47 \%$ nucleotide sequence identity with genotypes 1, 2, 3, $4 \mathrm{HEV}$, and avian HEV, respectively. The capsid protein of the rabbit HEV crossreacted with antibodies raised against avian, rat, swine, and human HEV. ${ }^{38}$ Since the rabbit HEV belongs to the zoonotic genotype 3, thus the rabbit HEV may infect humans. Under experimental conditions, the rabbit HEV was successfully transmitted to pigs, ${ }^{38}$ further demonstrating the ability of cross-species infection by rabbit HEV.

\section{Deer}

Antibodies to HEV have been detected in sika deer, Yezo deer, and red deer. ${ }^{39-41}$ Strains of genotype $3 \mathrm{HEV}$ have been genetically identified from sika deer in Japan and roe deer in Hungary. ${ }^{42,43}$ HEV transmission from deer to humans via the consumption of contaminated deer meat has been documented. ${ }^{44,45}$

\section{Mongoose}

Approximately 8 to $21 \%$ of the mongooses in Japan were seropositive for HEV antibodies. ${ }^{46}$ Strains of genotype $3 \mathrm{HEV}$ have been genetically identified from mongoose. ${ }^{47}$ Whether the mongoose HEV infects humans remains unknown, although genotype $3 \mathrm{HEV}$ is known to be zoonotic.

\section{Bat}

Drexler et al $^{9}$ tested 3,869 bat samples from 85 different bat species worldwide for HEV RNA. Novel strains of HEV were identified from African, Central American, and European bats. The bat HEV forms a novel phylogenetic clade belonging to a separate genus within the family Hepeviridae. Evidence of HEV transmission from bats to humans was absent.

\section{Ferret}

A unique strain of HEV was genetically identified from ferrets in the Netherlands. ${ }^{13}$ The ferret HEV shared the highest nucleotide sequence identity (72.3\%) with the putative new genotype of rat HEV. Phylogenetic analysis revealed that the ferret HEV was distinct from the known genotype 1-4 mammalian HEV in the proposed Orthohepevirus genus and 
clustered with the putative new genotype of rat HEV (-Table 1).

\section{Fish}

The CTV isolated from spawning adult trout in the United States $^{10}$ shares only approximately 13 to $27 \%$ amino acid sequence identity with the proposed genera Orthohepevirus and Avihepevirus, and therefore likely belongs to another new proposed genus Piscihepevirus (-Table 1). Unlike other strains of HEV, CTV can be efficiently propagated in the Chinook salmon embryo (CHSE-214) cell line.

\section{Cattle}

Antibodies to HEV have been detected in cattle from different countries. A 189-bp sequence of HEV was reportedly amplified from the fecal samples of eight cows in China, and the bovine $\mathrm{HEV}$ appears to be a genotype $4 .{ }^{48}$

\section{Sheep}

Serological evidence of HEV infection in sheep has been reported in China and Spain. A short 189-bp sequence of HEV was amplified from six sheep fecal samples in China by the same laboratory that reported the sequence of bovine $\mathrm{HEV},{ }^{49}$ and the sheep HEV also appears to be a genotype 4 . The genotype $4 \mathrm{HEV}$-like sequences reportedly amplified from sheep and cattle require further independent confirmation.

\section{Other Potential Animal Reservoirs}

In addition to the animal species described above from which strains of HEV have been genetically identified, serological evidence of HEV infection has been reported in several other animal species such as dog, cat, goat, and nonhuman primates, ${ }^{50,51}$ suggesting that these animals have been exposed to HEV as well. Identification of the source of seropositivity from these animal species will likely discover new HEV strains and further expand the host range and animal reservoirs of HEV.

\section{Zoonotic Transmission of HEV}

Zoonotic transmission is responsible for the sporadic and cluster cases of human hepatitis E caused by genotypes 3 and 4. ${ }^{5}$ Cases of persistent hepatitis $\mathrm{E}$ in immunocompromised individuals are also linked to the zoonotic genotype $3 \mathrm{HEV}$ infection. $^{4}$

\section{Cross-Species Infection by HEV}

Genotypes 1 and 2 HEV have a limited host range and are restricted to humans: Attempts to experimentally infect pig, rat, and goat with genotypes 1 and 2 human HEV were unsuccessful. ${ }^{52,53}$ In contrast, genotypes 3 and 4 HEV have a much broader host range and can infect across species barriers: genotypes 3 and 4 swine HEV infected nonhuman primates, ${ }^{54,55}$ and conversely genotypes 3 and 4 human HEV infected pigs. ${ }^{24,54,56,57}$ Cross-species HEV infection has also been reported in other animal species ( $\mathbf{- F i g . 1}$ ). Lambs and Wistar rats were reportedly infected by human HEV isolates of presumably genotype 1 origin, ${ }^{58,59}$ although others failed to infect goats or rat with genotypes 1 and 2 HEV. ${ }^{53}$ The avian HEV from a chicken successfully infected turkeys, ${ }^{60}$ but failed to infect two rhesus monkeys, ${ }^{32}$ suggesting that avian HEV is likely not zoonotic and may not infect humans. The strains of HEV from rabbits infected pigs ${ }^{38}$ and genotypes 1 and 4 human HEV also reportedly infected rabbits. ${ }^{61}$ The mechanisms and genetic determinant(s) of cross-species HEV infection remain unknown.

\section{Pigs as a Reservoir for Zoonotic HEV Transmission}

It has been demonstrated that pig handlers such as pig farmers and swine veterinarians are at increased risk of HEV infection. ${ }^{62-67}$ For example, swine veterinarians in the United States were 1.51 times more likely to be positive for HEV antibodies than age- and geography-matched normal blood donors. ${ }^{62}$ Individuals from traditionally major swine states such as Minnesota are more likely seropositive for HEV antibodies than those from traditionally nonswine States such as Alabama. In North Carolina, swine workers had a 4.5-fold higher HEV antibody prevalence rate than the control subjects. ${ }^{68}$ In Moldova, approximately $51 \%$ of swine farmers were seropositive for HEV antibodies, whereas only $25 \%$ of control subjects with no occupational exposure to swine were seropositive. ${ }^{65} \mathrm{Pig}$ is now a recognized reservoir for zoonotic HEV infection, and direct human contact with infected pigs poses a risk for HEV infection.

\section{Other Animal Reservoirs for Zoonotic HEV Transmission}

In addition to pigs, other animal species such as deer and rabbit also serve as potential reservoirs for HEV. For examples, zoonotic transmissions of hepatitis $\mathrm{E}$ from deer to humans and from a pet cat to human owner were reported. ${ }^{44,45,69,70}$ Workers from the Iowa Department of Natural Resources (DNR) who had contacts with wildlife animal species had a higher HEV antibody prevalence rate than normal blood donors $(p<0.05) .{ }^{71}$ Understanding the natural history and mechanisms of cross-species infection of HEV will be critical for effectively preventing zoonotic human infection by HEV.

\section{Zoonotic Source of Virus for Persistent Infection in Immunocompromised Individuals}

Recently, persistent HEV infection has become an emerging and significant clinical problem with considerable morbidity and mortality in immunocompromised individuals such as organ transplant recipients, ${ }^{6,7,72-75}$ patients with HIV infections, ${ }^{76-80}$ non-Hodgkin lymphoma, ${ }^{81}$ and lymphoblastic leukemia. ${ }^{82}$ Approximately 58 to $92 \%$ of the HEV-infected organ transplant recipients developed persistent infection. ${ }^{7,83,84}$ Thus far, cases of persistent infections are almost exclusively caused by strains of HEV belonging to the genotype $3,{ }^{72,84}$ suggesting that the source of infection is likely zoonotic in nature. ${ }^{83,85}$ In immunocompetent individuals, a lower dose of virus exposure through direct contact with infected animals or consumption of undercooked animal meat may only result in subclinical or self-limiting acute infection because hepatitis $\mathrm{E}$ is known to be a dose-dependent disease: A high dose causes biochemical and clinical hepatitis whereas a low dose causes only subclinical infection. ${ }^{86}$ 
However, in immunocompromised individuals that cannot effectively clear the virus even exposed at a low dose, the infection can progress into chronicity. Therefore, individuals with immunosuppressive conditions should avoid eating undercooked animal meat or contact with potentially HEVinfected animals.

\section{Foodborne Transmission of HEV}

\section{Animal Meat Products as the Sources for Foodborne Transmission}

Approximately $2 \%$ of the pig livers sold in local grocery stores in Japan, ${ }^{87} 4 \%$ in Germany, ${ }^{88} 6.5 \%$ in the Netherlands, ${ }^{89}$ and $11 \%$ in the United States ${ }^{90}$ tested positive for the zoonotic genotype 3 HEV RNA. The contaminating virus in the commercial pig livers remains fully infectious, ${ }^{90}$ and incubation of the contaminated meat at a temperature $\left(56^{\circ} \mathrm{C}\right)$ equivalent to a medium-to-rare cooking condition did not inactivate the virus completely. ${ }^{91}$ Many sporadic and cluster cases of hepatitis E have been linked to the consumption of contaminated raw or undercooked animal meat and meat products. ${ }^{92-95}$ For example, severe hepatitis E developed in a Japanese man after consumption of contaminated wild boar meat; another man contracted fulminant hepatitis after eating the same wild boar meat. ${ }^{93,94}$ The zoonotic genotype $4 \mathrm{HEV}$ was detected from the patient serum and wild boars with indistinguishable nucleotide sequences. A cluster case of hepatitis E patients was linked to the consumption of raw deer meats in Japan. ${ }^{44}$ Importantly, the HEV sequence amplified from the leftover frozen deer meat was nearly identical to the HEV sequence amplified from the patients. Additionally, consumption of game meat is also a risk factor for HEV infection. ${ }^{83}$

It appears that large pork production chains in some countries are contaminated by HEV, which raises a public health concern for potential foodborne HEV transmission because of the high-volume consumption of pork products worldwide. In the United Kingdom, HEV was detected in pig livers in a slaughterhouse, in surface samples from a processing plant, and in pork sausages and surface samples at the point of sale. ${ }^{96}$ In Czech Republic, Italy, and Spain, among the 337 fecal, liver, and meat samples from pigs at slaughterhouses tested, HEV RNA was detected in $41 \%$ (Italy) and $41 \%$ (Spain) fecal samples, 5\% liver and 2.5\% meat (Czech Republic). ${ }^{97}$ Approximately $6 \%$ of the sausages sampled at processing and at the point of sale in Spain were also positive for genotype 3 HEV RNA. ${ }^{97}$ In France, pig liver sausages (figatelli) were responsible for some sporadic cases of hepatitis E. ${ }^{98}$ Acute or recent HEV infection was observed in 7 of 13 individuals who ate figatellu, but in none of the 5 individuals who did not eat figatellu. The genotype $3 \mathrm{HEV}$ sequences amplified from 7 of the 12 figatelli from supermarkets were genetically linked to the patients who ate figatellu. In Japan, foodborne HEV transmission has been demonstrated in Kitami and Abashiri via consumption of grilled pig entrails. ${ }^{99}$

The potential widespread dissemination of HEV through pork production chains and the hidden danger of potential subsequent foodborne transmission especially in immunocompromised individuals are of significant concerns. ${ }^{100}$
Taken together, these data clearly showed that foodborne transmission is an important route of HEV transmission that is responsible for the sporadic and cluster cases of hepatitis $\mathrm{E}$ worldwide.

\section{Contaminated Shellfish as the Source for Foodborne Transmission}

HEV replicates in the liver as well as in gastrointestinal tract, ${ }^{56,101}$ and infected humans and other animals excreted large amounts of HEV in feces, ${ }^{57,102}$ which poses a concern for environmental contamination and food safety. HEV has been detected in swine manure and wastewater associated with hog operations, ${ }^{71}$ and in concrete pits and lagoons of swine manure storage facilities in the United States. ${ }^{102}$ Genotype 3 HEV RNA was detected in swine manure collected from concrete holding pits and from lagoons on pig farms; importantly, the HEV detected in pig manure slurry remains infectious. ${ }^{102}$ In Korea, HEV RNA resembling the genotype 3 swine HEV was detected in oysters. ${ }^{103}$ Consumption of contaminated shellfish has been implicated in sporadic cases of acute hepatitis E. ${ }^{104-106}$ An outbreak of hepatitis E on a cruise ship was linked to the consumption of shellfish while on board. ${ }^{107}$ Therefore, contaminated shellfish is an emerging source of foodborne HEV transmission.

\section{Contaminated Water as the Source for Foodborne and Waterborne Transmission}

Contamination of water by HEV from human and other animal wastes can lead to subsequent contamination of food and produce, and thus leading to potential foodborne transmission. ${ }^{3,108,109}$ Historically, waterborne epidemics are the characteristic of hepatitis E outbreaks in humans in regions where sanitation conditions are poor. ${ }^{1}$ Untreated sewage water contamination of drinking water and contaminated well or river water used for washing and drinking purpose are the main sources of HEV transmission in developing countries. ${ }^{110}$ In India, a significantly higher prevalence of HEV antibodies was detected in sewage workers (57\%) than in controls (19\%), and sewage workers with $>5$ years of employment history had a much higher seropositivity rate. ${ }^{111}$ In HEV endemic regions, the use of river water for bathing, waste disposal, and drinking purposes is also a significant risk factor. ${ }^{112-115}$ In Turkey, individuals who used untreated waste water for irrigation purposes have a significant higher HEV antibody prevalence rate $(34.8 \%)$ than the control subjects with similar age and socioeconomic status. ${ }^{116}$

In industrialized countries with good sanitation conditions and water treatment measures, outbreaks of waterborne HEV transmission are rare. However, the existence of numerous zoonotic strains of HEV from various animal species implies that land application and runoffs of HEVcontaining animal manure and feces could contaminate irrigation or coastal water with concomitant contamination of produce or shellfish, $3,102,109$ thus posing a risk of foodborne and waterborne HEV transmission. For example, in Canada, genotype $3 \mathrm{HEV}$ of swine origin was detected on irrigated field-grown strawberries; irrigation water was suspected as the source of the strawberry contamination. ${ }^{117}$ Strains of 
infectious HEV of both human and swine origins have been detected in sewage water in industrialized countries. ${ }^{118-122}$ Therefore, contaminated water could be a source of food contamination, thus leading to foodborne HEV transmission.

\section{Other Uncommon Routes of HEV Transmission}

\section{Vertical Transmission}

Vertical HEV transmissions from mother-to-fetus were reportedly associated with a high neonatal mortality, including premature birth, increased fetal loss and acute hepatitis in the newborns. ${ }^{123-125}$ For example, vertical HEV transmission was detected in approximately $33 \%$ of HEV-infected pregnant women. ${ }^{124}$ HEV RNA was reportedly detected in the colostrum of HEV-infected mothers, although breast-feeding appears to be safe for the infants. ${ }^{126}$ Under experimental conditions, however, vertical HEV transmission in animal models has not been demonstrated. For example, infectious HEV was detected in egg whites from embryonated eggs hatched from chickens infected experimentally with an avian strain of HEV, but there was no evidence of complete vertical transmission. ${ }^{127}$ Also, pregnant sows inoculated with a genotype $3 \mathrm{HEV}$ became infected, but vertical transmission to the fetuses was not detected. ${ }^{128}$ Similarly, pregnant rhesus macaques experimentally infected with HEV failed to transmit the virus to offspring. ${ }^{129}$ Therefore, further in-depth studies are warranted to definitively understand the potential risk of vertical HEV transmission.

\section{Blood-Borne Transmission}

Bloodborne transmission of HEV through blood transfusions, although rare, has been documented. ${ }^{95,130-134}$ For example, some blood donors have tested positive for HEV RNA. In Japan, HEV RNA was detected in 8 of the 41 blood donors with elevated ALT levels. ${ }^{135-138}$ Screening donor blood for acute markers of HEV infection will reduce the risk of potential bloodborne transmission.

\section{Prevention of Foodborne and Zoonotic Transmission of HEV}

A vaccine against HEV in humans was recently licensed for use in China, but not in other countries. ${ }^{139}$ In the absence of a vaccine in most parts of the world, preventive measures such as good hygiene practice and avoidance of drinking water of unknown purity are necessary to minimize the risk of HEV infection. Because swine and several other animal species are reservoirs for HEV, an important measure to prevent zoonotic infection is to wash hands thoroughly with soap and water after handling pigs and other infected animals. The majority of the sporadic and cluster cases of hepatitis E are associated with the consumption of raw or undercooked animal meat products; therefore, an important preventive measure for foodborne HEV transmission, especially in immunocompromised individuals, is to avoid eating undercooked animal meat. Even though HEV infection in pigs is nonpathogenic, it will still be advantageous for the swine industry to develop a vaccine against HEV infections in pigs because such an animal vaccine will minimize the risk of zoonotic transmission and increase pork safety. ${ }^{3}$

\section{References}

1 Emerson SU, Purcell RH. Hepatitis E virus. In: Knipe DM HPe, ed. Fields Virology. 5th ed. Philadelphia: Lippincott Williams \& Wilkins; 2007:3047-3058

2 Hoofnagle JH, Nelson KE, Purcell RH. Hepatitis E. N Engl J Med 2012;367(13):1237-1244

3 Meng XJ. From barnyard to food table: the omnipresence of hepatitis $\mathrm{E}$ virus and risk for zoonotic infection and food safety. Virus Res 2011;161(1):23-30

4 Meng XJ. Recent advances in hepatitis E virus. J Viral Hepat 2010;17(3):153-161

5 Meng XJ. Hepatitis E virus: animal reservoirs and zoonotic risk. Vet Microbiol 2010;140(3-4):256-265

6 Kamar N, Garrouste C, Haagsma EB, et al. Factors associated with chronic hepatitis in patients with hepatitis $\mathrm{E}$ virus infection who have received solid organ transplants. Gastroenterology 2011; 140(5):1481-1489

7 Kamar N, Selves J, Mansuy JM, et al. Hepatitis E virus and chronic hepatitis in organ-transplant recipients. N Engl J Med 2008;358 (8):811-817

8 Meng XJ, Anderson DA, Arankalle VA, Emerson SU, Harrison TJ, Jameel S, Okamoto H. Hepeviridae. In: King AMQ Adams MJ, Carstens EB, Lefkowitz EJ, eds. Virus Taxonomy, 9th Report of the ICTV. London: Elsevier Academic Press; 2012:1021-1028

9 Drexler JF, Seelen A, Corman VM, et al. Bats worldwide carry hepatitis $E$ virus-related viruses that form a putative novel genus within the family Hepeviridae. J Virol 2012;86(17):9134-9147

10 Batts W, Yun S, Hedrick R, Winton J. A novel member of the family Hepeviridae from cutthroat trout (Oncorhynchus clarkii). Virus Res 2011;158(1-2):116-123

11 Johne R, Plenge-Bönig A, Hess M, Ulrich RG, Reetz J, Schielke A. Detection of a novel hepatitis E-like virus in faeces of wild rats using a nested broad-spectrum RT-PCR. J Gen Virol 2010; 91(Pt 3):750-758

12 Purcell RH, Engle RE, Rood MP, et al. Hepatitis E virus in rats, Los Angeles, California, USA. Emerg Infect Dis 2011;17(12): 2216-2222

13 Raj VS, Smits SL, Pas SD, et al. Novel hepatitis E virus in ferrets, the Netherlands. Emerg Infect Dis 2012;18(8):1369-1370

14 Sato Y, Sato H, Naka K, et al. A nationwide survey of hepatitis E virus (HEV) infection in wild boars in Japan: identification of boar HEV strains of genotypes 3 and 4 and unrecognized genotypes. Arch Virol 2011;156(8):1345-1358

15 Takahashi M, Nishizawa T, Sato $\mathrm{H}$, et al. Analysis of the full-length genome of a hepatitis $\mathrm{E}$ virus isolate obtained from a wild boar in Japan that is classifiable into a novel genotype. J Gen Virol 2011;92(Pt 4):902-908

16 Haqshenas G, Shivaprasad HL, Woolcock PR, Read DH, Meng XJ. Genetic identification and characterization of a novel virus related to human hepatitis $\mathrm{E}$ virus from chickens with hepatitis-splenomegaly syndrome in the United States. J Gen Virol 2001;82(Pt 10):2449-2462

17 Huang FF, Haqshenas G, Shivaprasad HL, et al. Heterogeneity and seroprevalence of a newly identified avian hepatitis $\mathrm{E}$ virus from chickens in the United States. J Clin Microbiol 2002; 40(11):4197-4202

18 Haqshenas G, Huang FF, Fenaux M, et al. The putative capsid protein of the newly identified avian hepatitis $\mathrm{E}$ virus shares antigenic epitopes with that of swine and human hepatitis $\mathrm{E}$ viruses and chicken big liver and spleen disease virus. J Gen Virol 2002;83(Pt 9):2201-2209 
19 Bilic I, Jaskulska B, Basic A, Morrow CJ, Hess M. Sequence analysis and comparison of avian hepatitis E viruses from Australia and Europe indicate the existence of different genotypes. J Gen Virol 2009;90(Pt 4):863-873

20 Meng XJ, Shivaprasad HS, Payne C. Hepatitis E virus infections. In: Saif YM, ed. Diseases of Poultry. 12th ed. Oxford: Blackwell Publishing; 2008:443-452

21 Marek A, Bilic I, Prokofieva I, Hess M. Phylogenetic analysis of avian hepatitis E virus samples from European and Australian chicken flocks supports the existence of a different genus within the Hepeviridae comprising at least three different genotypes. Vet Microbiol 2010;145(1-2):54-61

22 Kwon HM, Sung HW, Meng XJ. Serological prevalence, genetic identification, and characterization of the first strains of avian hepatitis E virus from chickens in Korea. Virus Genes 2012; 45(2):237-245

23 Meng XJ, Purcell RH, Halbur PG, et al. A novel virus in swine is closely related to the human hepatitis E virus. Proc Natl Acad Sci U S A 1997;94(18):9860-9865

24 Halbur PG, Kasorndorkbua C, Gilbert C, et al. Comparative pathogenesis of infection of pigs with hepatitis $\mathrm{E}$ viruses recovered from a pig and a human. J Clin Microbiol 2001;39(3):918-923

25 Kasorndorkbua C, Halbur PG, Thomas PJ, Guenette DK, Toth TE, Meng XJ. Use of a swine bioassay and a RT-PCR assay to assess the risk of transmission of swine hepatitis $\mathrm{E}$ virus in pigs. J Virol Methods 2002;101(1-2):71-78

26 Kasorndorkbua C, Guenette DK, Huang FF, Thomas PJ, Meng XJ, Halbur PG. Routes of transmission of swine hepatitis E virus in pigs. J Clin Microbiol 2004;42(11):5047-5052

27 Meng XJ, Lindsay DS, Sriranganathan N. Wild boars as sources for infectious diseases in livestock and humans. Philos Trans R Soc Lond B Biol Sci 2009;364(1530):2697-2707

28 Payne CJ, Ellis TM, Plant SL, Gregory AR, Wilcox GE. Sequence data suggests big liver and spleen disease virus (BLSV) is genetically related to hepatitis E virus. Vet Microbiol 1999;68(1-2):119-125

29 Sun ZF, Larsen CT, Dunlop A, et al. Genetic identification of avian hepatitis $\mathrm{E}$ virus (HEV) from healthy chicken flocks and characterization of the capsid gene of 14 avian HEV isolates from chickens with hepatitis-splenomegaly syndrome in different geographical regions of the United States. J Gen Virol 2004; 85(Pt 3):693-700

30 Billam P, LeRoith T, Pudupakam RS, Pierson FW, Duncan RB, Meng $\mathrm{XJ}$. Comparative pathogenesis in specific-pathogen-free chickens of two strains of avian hepatitis E virus recovered from a chicken with hepatitis-splenomegaly syndrome and from a clinically healthy chicken. Vet Microbiol 2009;139(3-4):253-261

31 Billam P, Huang FF, Sun ZF, et al. Systematic pathogenesis and replication of avian hepatitis $\mathrm{E}$ virus in specific-pathogen-free adult chickens. J Virol 2005;79(6):3429-3437

32 Huang FF, Sun ZF, Emerson SU, et al. Determination and analysis of the complete genomic sequence of avian hepatitis $\mathrm{E}$ virus (avian HEV) and attempts to infect rhesus monkeys with avian HEV. J Gen Virol 2004;85(Pt 6):1609-1618

33 Johne R, Dremsek P, Kindler E, et al. Rat hepatitis E virus: geographical clustering within Germany and serological detection in wild Norway rats (Rattus norvegicus). Infect Genet Evol 2012;12(5):947-956

34 Lack JB, Volk K, Van Den Bussche RA. Hepatitis E virus genotype 3 in wild rats, United States. Emerg Infect Dis 2012;18(8):1268-1273

35 Zhao C, Ma Z, Harrison TJ, et al. A novel genotype of hepatitis E virus prevalent among farmed rabbits in China. J Med Virol 2009;81(8):1371-1379

36 Cossaboom CM, Córdoba L, Dryman BA, Meng XJ. Hepatitis E virus in rabbits, Virginia, USA. Emerg Infect Dis 2011;17(11): 2047-2049

37 Izopet J, Dubois M, Bertagnoli S, et al. Hepatitis E virus strains in rabbits and evidence of a closely related strain in humans, France. Emerg Infect Dis 2012;18(8):1274-1281
38 Cossaboom CM, Córdoba L, Sanford BJ, et al. Cross-species infection of pigs with a novel rabbit, but not rat, strain of hepatitis E virus isolated in the United States. J Gen Virol 2012; 93(Pt 8):1687-1695

39 Boadella M, Casas M, Martín M, et al. Increasing contact with hepatitis E virus in red deer, Spain. Emerg Infect Dis 2010; 16(12):1994-1996

40 Tomiyama D, Inoue E, Osawa Y, Okazaki K. Serological evidence of infection with hepatitis E virus among wild Yezo-deer, Cervus nippon yesoensis, in Hokkaido, Japan. J Viral Hepat 2009;16 (7):524-528

41 Rutjes SA, Lodder-Verschoor F, Lodder WJ, et al. Seroprevalence and molecular detection of hepatitis $\mathrm{E}$ virus in wild boar and red deer in The Netherlands. J Virol Methods 2010; 168(1-2):197-206

42 Takahashi K, Kitajima N, Abe N, Mishiro S. Complete or nearcomplete nucleotide sequences of hepatitis $\mathrm{E}$ virus genome recovered from a wild boar, a deer, and four patients who ate the deer. Virology 2004;330(2):501-505

43 Reuter G, Fodor D, Forgách P, Kátai A, Szucs G. Characterization and zoonotic potential of endemic hepatitis E virus (HEV) strains in humans and animals in Hungary. J Clin Virol 2009; 44(4):277-281

44 Tei S, Kitajima N, Takahashi K, Mishiro S. Zoonotic transmission of hepatitis E virus from deer to human beings. Lancet 2003;362 (9381):371-373

45 Tei S, Kitajima N, Ohara S, et al. Consumption of uncooked deer meat as a risk factor for hepatitis $\mathrm{E}$ virus infection: an age- and sex-matched case-control study. J Med Virol 2004;74(1):67-70

46 Li TC, Saito M, Ogura G, Ishibashi O, Miyamura T, Takeda N. Serologic evidence for hepatitis $\mathrm{E}$ virus infection in mongoose. Am J Trop Med Hyg 2006;74(5):932-936

47 Nakamura M, Takahashi K, Taira K, et al. Hepatitis E virus infection in wild mongooses of Okinawa, Japan: Demonstration of anti-HEV antibodies and a full-genome nucleotide sequence. Hepatol Res 2006;34(3):137-140

$48 \mathrm{Hu}$ GD, Ma X. [Detection and sequences analysis of bovine hepatitis E virus RNA in Xinjiang Autonomous Region]. Bing Du Xue Bao 2010;26(1):27-32

49 Wang Y, Ma X. [Detection and sequences analysis of sheep hepatitis E virus RNA in Xinjiang autonomous region]. Wei sheng wu xue bao. [Acta Microbiol Sin] 2010;50:937-941

50 Meng XJ. Hepatitis E as a zoonosis. In: Thomas AZ, Lemon S, eds. Viral Hepatitis, 3rd ed. Oxford: Blackwell Publishing Ltd; 2005:611-623

51 Meng XJ. Novel strains of hepatitis E virus identified from humans and other animal species: is hepatitis E a zoonosis? J Hepatol 2000;33(5):842-845

52 Meng XJ, Halbur PG, Haynes JS, et al. Experimental infection of pigs with the newly identified swine hepatitis E virus (swine HEV), but not with human strains of HEV. Arch Virol 1998; 143(7):1405-1415

53 Sanford BJ, Emerson SU, Purcell RH, et al. Serological evidence for a hepatitis E virus (HEV)-related agent in goats in the United States. Transboundary Emerg Dis 2012 Aug 22. Epub ahead of print

54 Meng XJ, Halbur PG, Shapiro MS, et al. Genetic and experimental evidence for cross-species infection by swine hepatitis $\mathrm{E}$ virus. J Virol 1998;72(12):9714-9721

55 Arankalle VA, Chobe LP, Chadha MS. Type-IV Indian swine HEV infects rhesus monkeys. J Viral Hepat 2006;13(11):742-745

56 Williams TP, Kasorndorkbua C, Halbur PG, et al. Evidence of extrahepatic sites of replication of the hepatitis E virus in a swine model. J Clin Microbiol 2001;39(9):3040-3046

57 Feagins AR, Opriessnig T, Huang YW, Halbur PG, Meng XJ. Crossspecies infection of specific-pathogen-free pigs by a genotype 4 strain of human hepatitis E virus. J Med Virol 2008;80(8): 1379-1386 
58 Usmanov RK, Balaian MS, Dvonikova OV, et al. [An experimental infection in lambs by the hepatitis E virus]. Vopr Virusol 1994; 39(4):165-168

59 Maneerat Y, Clayson ET, Myint KS, Young GD, Innis BL. Experimental infection of the laboratory rat with the hepatitis E virus. J Med Virol 1996;48(2):121-128

60 Sun ZF, Larsen CT, Huang FF, et al. Generation and infectivity titration of an infectious stock of avian hepatitis E virus (HEV) in chickens and cross-species infection of turkeys with avian HEV. J Clin Microbiol 2004;42(6):2658-2662

$61 \mathrm{Ma} \mathrm{H}$, Zheng L, Liu Y, et al. Experimental infection of rabbits with rabbit and genotypes 1 and 4 hepatitis E viruses. PLoS ONE 2010; 5(2):e9160

62 Meng XJ, Wiseman B, Elvinger F, et al. Prevalence of antibodies to hepatitis $\mathrm{E}$ virus in veterinarians working with swine and in normal blood donors in the United States and other countries. J Clin Microbiol 2002;40(1):117-122

63 Meng XJ. Swine hepatitis E virus: cross-species infection and risk in xenotransplantation. Curr Top Microbiol Immunol 2003;278: 185-216

64 Adjei AA, Aviyase JT, Tettey Y, et al. Hepatitis E virus infection among pig handlers in Accra, Ghana. East Afr Med J 2009; 86(8):359-363

65 Drobeniuc J, Favorov MO, Shapiro CN, et al. Hepatitis E virus antibody prevalence among persons who work with swine. $J$ Infect Dis 2001;184(12):1594-1597

66 Olsen B, Axelsson-Olsson D, Thelin A, Weiland O. Unexpected high prevalence of IgG-antibodies to hepatitis E virus in Swedish pig farmers and controls. Scand J Infect Dis 2006;38(1):55-58

67 Pourpongporn P, Samransurp K, Rojanasang P, Wiwattanakul S, Srisurapanon S. The prevalence of anti-hepatitis E in occupational risk groups. J Med Assoc Thai 2009;92(Suppl 3):S38-S42

68 Withers MR, Correa MT, Morrow M, et al. Antibody levels to hepatitis E virus in North Carolina swine workers, non-swine workers, swine, and murids. Am J Trop Med Hyg 2002;66(4):384-388

69 Kuno A, Ido K, Isoda $\mathrm{N}$, et al. Sporadic acute hepatitis $\mathrm{E}$ of a 47-year-old man whose pet cat was positive for antibody to hepatitis E virus. Hepatol Res 2003;26(3):237-242

70 Renou C, Cadranel JF, Bourlière M, et al. Possible zoonotic transmission of hepatitis E from pet pig to its owner. Emerg Infect Dis 2007;13(7):1094-1096

71 Karetnyi YV, Gilchrist MJ, Naides SJ. Hepatitis E virus infection prevalence among selected populations in Iowa. J Clin Virol 1999;14(1):51-55

72 Wedemeyer H, Pischke S, Manns MP. Pathogenesis and treatment of hepatitis e virus infection. Gastroenterology 2012;142(6): 1388-1397, e1

73 Suneetha PV, Pischke S, Schlaphoff V, et al. Hepatitis E virus (HEV)-specific T-cell responses are associated with control of HEV infection. Hepatology 2012;55(3):695-708

74 Pas SD, de Man RA, Mulders C, et al. Hepatitis E virus infection among solid organ transplant recipients, the Netherlands. Emerg Infect Dis 2012;18(5):869-872

75 Kamar N, Mansuy JM, Cointault O, et al. Hepatitis E virus-related cirrhosis in kidney- and kidney-pancreas-transplant recipients. Am J Transplant 2008;8(8):1744-1748

76 Kenfak-Foguena A, Schöni-Affolter F, Bürgisser P, et al; Data Center of the Swiss HIV Cohort Study, Lausanne, Switzerland. Hepatitis E Virus seroprevalence and chronic infections in patients with HIV, Switzerland. Emerg Infect Dis 2011;17(6): 1074-1078

77 Jardi R, Crespo M, Homs M, et al. HIV, HEV and cirrhosis: evidence of a possible link from eastern Spain. HIV Med 2012; 13(6):379-383

78 Jagjit Singh GK, Ijaz S, Rockwood N, et al. Chronic Hepatitis E as a cause for cryptogenic cirrhosis in HIV. J Infect 2013;66(1):103-106

79 Dalton HR, Keane FE, Bendall R, Mathew J, Ijaz S. Treatment of chronic hepatitis $\mathrm{E}$ in a patient with HIV infection. Ann Intern Med 2011;155(7):479-480
80 Dalton HR, Bendall RP, Keane FE, Tedder RS, Ijaz S. Persistent carriage of hepatitis $\mathrm{E}$ virus in patients with HIV infection. $\mathrm{N}$ Engl J Med 2009;361(10):1025-1027

81 Ollier L, Tieulie N, Sanderson F, et al. Chronic hepatitis after hepatitis $\mathrm{E}$ virus infection in a patient with non-Hodgkin lymphoma taking rituximab. Ann Intern Med 2009;150(6): 430-431

82 Motte A, Roquelaure B, Galambrun C, Bernard F, Zandotti C, Colson P. Hepatitis E in three immunocompromized children in southeastern France. J Clin Virol 2012;53(2):162-166

83 Legrand-Abravanel F, Kamar N, Sandres-Saune K, et al. Characteristics of autochthonous hepatitis E virus infection in solid-organ transplant recipients in France. J Infect Dis 2010;202(6):835-844

84 Kamar N, Weclawiak H, Guilbeau-Frugier C, et al. Hepatitis E virus and the kidney in solid-organ transplant patients. Transplantation 2012;93(6):617-623

85 Moal V, Gerolami R, Colson P. First human case of co-infection with two different subtypes of hepatitis $\mathrm{E}$ virus. Intervirology 2012;55(6):484-487

86 Tsarev SA, Tsareva TS, Emerson SU, et al. Infectivity titration of a prototype strain of hepatitis E virus in cynomolgus monkeys. J Med Virol 1994;43(2):135-142

87 Yazaki Y, Mizuo H, Takahashi M, et al. Sporadic acute or fulminant hepatitis $\mathrm{E}$ in Hokkaido, Japan, may be food-borne, as suggested by the presence of hepatitis E virus in pig liver as food. J Gen Virol 2003;84(Pt 9):2351-2357

88 Wenzel JJ, Preiss J, Schemmerer M, Huber B, Plentz A, Jilg W. Detection of hepatitis E virus (HEV) from porcine livers in southeastern Germany and high sequence homology to human HEV isolates. J Clin Virol 2011;52(1):50-54

89 Bouwknegt M, Lodder-Verschoor F, van der Poel WH, Rutjes SA, de Roda Husman AM. Hepatitis E virus RNA in commercial porcine livers in The Netherlands. J Food Prot 2007;70(12): 2889-2895

90 Feagins AR, Opriessnig T, Guenette DK, Halbur PG, Meng XJ. Detection and characterization of infectious Hepatitis $\mathrm{E}$ virus from commercial pig livers sold in local grocery stores in the USA. J Gen Virol 2007;88(Pt 3):912-917

91 Feagins AR, Opriessnig T, Guenette DK, Halbur PG, Meng XJ. Inactivation of infectious hepatitis $\mathrm{E}$ virus present in commercial pig livers sold in local grocery stores in the United States. Int J Food Microbiol 2008;123(1-2):32-37

92 Li TC, Chijiwa K, Sera N, et al. Hepatitis E virus transmission from wild boar meat. Emerg Infect Dis 2005;11(12):1958-1960

93 Masuda J, Yano K, Tamada Y, et al. Acute hepatitis E of a man who consumed wild boar meat prior to the onset of illness in Nagasaki, Japan. Hepatol Res 2005;31(3):178-183

94 Matsuda H, Okada K, Takahashi K, Mishiro S. Severe hepatitis E virus infection after ingestion of uncooked liver from a wild boar. J Infect Dis 2003;188(6):944

95 Matsubayashi K, Kang JH, Sakata H, et al. A case of transfusiontransmitted hepatitis $\mathrm{E}$ caused by blood from a donor infected with hepatitis E virus via zoonotic food-borne route. Transfusion 2008;48(7):1368-1375

96 Berto A, Martelli F, Grierson S, Banks M. Hepatitis E virus in pork food chain, United Kingdom, 2009-2010. Emerg Infect Dis 2012;18(8):1358-1360

97 Di Bartolo I, Diez-Valcarce M, Vasickova P, et al. Hepatitis E virus in pork production chain in Czech Republic, Italy, and Spain, 2010. Emerg Infect Dis 2012;18(8):1282-1289

98 Colson P, Borentain P, Queyriaux B, et al. Pig liver sausage as a source of hepatitis E virus transmission to humans. J Infect Dis 2010;202(6):825-834

99 Miyashita K, Kang JH, Saga A, et al. Three cases of acute or fulminant hepatitis $\mathrm{E}$ caused by ingestion of pork meat and entrails in Hokkaido, Japan: Zoonotic food-borne transmission of hepatitis E virus and public health concerns. Hepatol Res 2012;42(9):870-878 
100 Purcell RH, Emerson SU. Hidden danger: the raw facts about hepatitis E virus. J Infect Dis 2010;202(6):819-821

101 Billam P, Pierson FW, Li W, LeRoith T, Duncan RB, Meng XJ. Development and validation of a negative-strand-specific reverse transcription-PCR assay for detection of a chicken strain of hepatitis E virus: identification of nonliver replication sites. J Clin Microbiol 2008;46(8):2630-2634

102 Kasorndorkbua C, Opriessnig T, Huang FF, et al. Infectious swine hepatitis $\mathrm{E}$ virus is present in pig manure storage facilities on United States farms, but evidence of water contamination is lacking. Appl Environ Microbiol 2005;71(12):7831-7837

103 Song YJ, Jeong HJ, Kim YJ, et al. Analysis of complete genome sequences of swine hepatitis $\mathrm{E}$ virus and possible risk factors for transmission of HEV to humans in Korea. J Med Virol 2010; 82(4):583-591

104 Cacopardo B, Russo R, Preiser W, Benanti F, Brancati G, Nunnari A. Acute hepatitis E in Catania (eastern Sicily) 1980-1994. The role of hepatitis E virus. Infection 1997;25(5):313-316

105 Koizumi Y, Isoda N, Sato Y, et al. Infection of a Japanese patient by genotype 4 hepatitis e virus while traveling in Vietnam. J Clin Microbiol 2004;42(8):3883-3885

106 Renou C, Moreau X, Pariente A, et al; ANGH, France. A national survey of acute hepatitis $\mathrm{E}$ in France. Aliment Pharmacol Ther 2008;27(11):1086-1093

107 Said B, Ijaz S, Kafatos G, et al; Hepatitis E Incident Investigation Team. Hepatitis E outbreak on cruise ship. Emerg Infect Dis 2009;15(11):1738-1744

108 Pavio N, Meng XJ, Renou C. Zoonotic hepatitis E: animal reservoirs and emerging risks. Vet Res 2010;41(6):46

109 Smith JL. A review of hepatitis E virus. J Food Prot 2001; 64(4):572-586

110 Emerson SU, Purcell RH. Hepatitis E virus. Rev Med Virol 2003;13 (3):145-154

111 Vaidya SR, Tilekar BN, Walimbe AM, Arankalle VA. Increased risk of hepatitis $E$ in sewage workers from India. J Occup Environ Med 2003;45(11):1167-1170

112 Sedyaningsih-Mamahit ER, Larasati RP, Laras K, et al. First documented outbreak of hepatitis $\mathrm{E}$ virus transmission in Java, Indonesia. Trans R Soc Trop Med Hyg 2002;96(4):398-404

113 Toole MJ, Claridge F, Anderson DA, et al. Hepatitis E virus infection as a marker for contaminated community drinking water sources in Tibetan villages. Am J Trop Med Hyg 2006; 74(2):250-254

114 Corwin AL, Tien NT, Bounlu K, et al. The unique riverine ecology of hepatitis E virus transmission in South-East Asia. Trans R Soc Trop Med Hyg 1999;93(3):255-260

115 Bile K, Isse A, Mohamud O, et al. Contrasting roles of rivers and wells as sources of drinking water on attack and fatality rates in a hepatitis E epidemic in Somalia. Am J Trop Med Hyg 1994; 51(4):466-474

116 Ceylan A, Ertem M, Ilcin E, Ozekinci T. A special risk group for hepatitis E infection: Turkish agricultural workers who use untreated waste water for irrigation. Epidemiol Infect 2003; 131(1):753-756

117 Brassard J, Gagné MJ, Généreux M, Côté C. Detection of human food-borne and zoonotic viruses on irrigated, field-grown strawberries. Appl Environ Microbiol 2012;78(10):3763-3766

118 Clemente-Casares P, Pina S, Buti M, et al. Hepatitis E virus epidemiology in industrialized countries. Emerg Infect Dis 2003;9(4):448-454

119 Ippagunta SK, Naik S, Sharma B, Aggarwal R. Presence of hepatitis E virus in sewage in Northern India: frequency and seasonal pattern. J Med Virol 2007;79(12):1827-1831

120 Jothikumar N, Aparna K, Kamatchiammal S, Paulmurugan R, Saravanadevi S, Khanna P. Detection of hepatitis E virus in raw and treated wastewater with the polymerase chain reaction. Appl Environ Microbiol 1993;59(8):2558-2562

121 Pina S, Jofre J, Emerson SU, Purcell RH, Girones R. Characterization of a strain of infectious hepatitis $\mathrm{E}$ virus isolated from sewage in an area where hepatitis E is not endemic. Appl Environ Microbiol 1998;64(11):4485-4488

122 Pina S, Buti M, Cotrina M, Piella J, Girones R. HEV identified in serum from humans with acute hepatitis and in sewage of animal origin in Spain. J Hepatol 2000;33(5):826-833

123 Khuroo MS, Kamili S, Khuroo MS. Clinical course and duration of viremia in vertically transmitted hepatitis $\mathrm{E}$ virus (HEV) infection in babies born to HEV-infected mothers. J Viral Hepat 2009; 16(7):519-523

124 Kumar A, Beniwal M, Kar P, Sharma JB, Murthy NS. Hepatitis E in pregnancy. Int J Gynaecol Obstet 2004;85(3):240-244

125 Singh S, Agarwal S, Singh S, Tomar A. Supracardiac total anomalous pulmonary venous connection with severe rheumatic mitral valve disease. J Card Surg 2011;26(5):526-528

126 Chibber RM, Usmani MA, Al-Sibai MH. Should HEV infected mothers breast feed? Arch Gynecol Obstet 2004;270(1): $15-20$

127 Guo H, Zhou EM, Sun ZF, Meng XJ. Egg whites from eggs of chickens infected experimentally with avian hepatitis E virus contain infectious virus, but evidence of complete vertical transmission is lacking. J Gen Virol 2007;88(Pt 5):1532-1537

128 Kasorndorkbua C, Thacker BJ, Halbur PG, et al. Experimental infection of pregnant gilts with swine hepatitis E virus. Can J Vet Res 2003;67(4):303-306

129 Tsarev SA, Tsareva TS, Emerson SU, et al. Experimental hepatitis E in pregnant rhesus monkeys: failure to transmit hepatitis $\mathrm{E}$ virus (HEV) to offspring and evidence of naturally acquired antibodies to HEV. J Infect Dis 1995;172(1):31-37

130 Bajpai M, Gupta E. Transfusion-transmitted hepatitis E: is screening warranted? Indian J Med Microbiol 2011;29(4): 353-358

131 Boxall E, Herborn A, Kochethu G, et al. Transfusion-transmitted hepatitis $\mathrm{E}$ in a 'nonhyperendemic' country. Transfus Med 2006;16(2):79-83

132 Mitsui T, Tsukamoto Y, Yamazaki C, et al. Prevalence of hepatitis E virus infection among hemodialysis patients in Japan: evidence for infection with a genotype $3 \mathrm{HEV}$ by blood transfusion. J Med Virol 2004;74(4):563-572

133 Arankalle VA, Chobe LP. Retrospective analysis of blood transfusion recipients: evidence for post-transfusion hepatitis E. Vox Sang 2000;79(2):72-74

134 Tamura A, Shimizu YK, Tanaka T, et al. Persistent infection of hepatitis $\mathrm{E}$ virus transmitted by blood transfusion in a patient with T-cell lymphoma. Hepatol Res 2007;37(2):113-120

135 Fukuda S, Sunaga J, Saito N, et al. Prevalence of antibodies to hepatitis E virus among Japanese blood donors: identification of three blood donors infected with a genotype 3 hepatitis E virus. J Med Virol 2004;73(4):554-561

136 Fukuda S, Ishikawa M, Ochiai N, et al. Unchanged high prevalence of antibodies to hepatitis E virus (HEV) and HEV RNA among blood donors with an elevated alanine aminotransferase level in Japan during 1991-2006. Arch Virol 2007;152(9):1623-1635

137 Sakata H, Matsubayashi K, Takeda H, et al. A nationwide survey for hepatitis $\mathrm{E}$ virus prevalence in Japanese blood donors with elevated alanine aminotransferase. Transfusion 2008;48(12): 2568-2576

138 Adlhoch C, Kaiser M, Pauli G, Koch J, Meisel H. Indigenous hepatitis $\mathrm{E}$ virus infection of a plasma donor in Germany. Vox Sang 2009;97(4):303-308

139 Proffitt A. First HEV vaccine approved. Nat Biotechnol 2012; 30:300 